Journal of Home Economics, Volume 25, Number (1), 2015

$\begin{gathered}\text { Journal of Home Economics } \\ \text { Volume 25, Number (1), } 2015\end{gathered}$
$\begin{gathered}\text { Journal of Home } \\ \text { Economics }\end{gathered}$
http://homeEcon.menofia.edu.eg
BSSN 1110-2578
Emaluation the Nutritional Value of Kemmak and Baladi
M. El-Kholie, Tarek M. Abd El-Rahman
Amira A. Hamouda

Abstract

The quality of Baladi and Kemmak bread produced in Damietta Governorate were evaluated for chemical composition, rheological, physical properties and anti-nutritional values. Also, Baladi and Kemmak bread were supplemented with ferrous sulfate at level (16.6 $\mathrm{mg} / \mathrm{kg}$ ) which fed on rats groups, and iron binding capacity ( $\mathrm{mg} / \mathrm{dl}$ ) in rats was measured. The results showed that the protein, fat, fiber and carbohydrates contents of Baladi bread wheat flour (82\% extraction) were $11.78,1.67,1.15$ and $74.60 \%$ on wet weight basis, respectively while, the energy value was $360.55 \mathrm{kcal} / 100 \mathrm{~g}$. In case of Kemmak bread, the protein, fat, fiber and carbohydrates content of soft wheat flour (72\% extraction) were 15.06, 1.05, 0.03 and $71.9 \%$ on wet weight basis, respectively while, the energy value was $357.29 \mathrm{kcal} / 100 \mathrm{~g}$. Results of rheological properties indicated that water absorption, arrival time, dough development and degree of softening of Baladi bread (wheat flour $82 \%$ extraction) recorded the highest value compared with Kemmak bread, while, stability of Kemmak bread (soft flour $72 \%$ extraction) recorded the highest value. Elasticity, extensibility, P.N and energy of Kemmak bread recorded the highest value, compared with Baladi bread. The highest values of physical properties (weight, volume, specific volume and diameter) recorded with Baladi bread with significant differences. While, the lowest one recorded with Kemmak bread. On the other hand, Kemmak bread recorded higher values of spread ratio and thickness with significant differences compared with Baladi bread. Also, the tannins and phytates contents in Baladi bread were higher than Kemmak bread and Verse versa in oxalate content. The mean value of iron of rats group fed on Kemmak bread was higher when compared with group fed on Baladi bread and control group with significant differences $(\mathrm{p}<0.05)$, while the mean value of total iron 
binding capacity (TIBC) of Baladi bread rats group was higher when compared with control group with significant differences.

Key words: Baladi bread, Kemmak bread, Rats and Quality

\section{Introduction}

In Egypt, the total yield of bread grains does not satisfy the needs of the country. The total production of wheat grains covers only about $55 \%$ of the total needs. The way to overcome this problem is to search for the native cereal sources which could be used with wheat flour bread making. In Egypt, as well as the Middle East, the most popular type of bread is a flat (Baladi bread), circular loaf $(1 \mathrm{~cm}$ thickness, 10 to $30 \mathrm{~cm}$ diameter) consisting of two layers. It is commonly made from high extraction flour ( $82 \%$ ) and prepared by a straight dough method. Baladi bread dough is softer (70-75\% water), fermented to $2 \mathrm{~h}$ and baked at a substantially higher temperature $\left(400-500^{\circ} \mathrm{C}\right)$ for $1-2 \mathrm{~min}$ (Mousa et al., 1979). Rheology can be defined as the study of how materials deform, flow or fail when force is applied. The name is derivate from Greek word: Rheos, meaning the river, flowing, streaming. Therefore, rheology means "flow science". Rheological investigations not only include flow behaviour of liquids, but also deformation behaviour of solids. Normally, to measure rheological properties, the material is subjected to a controlled, précised and quantifiable distortion or strain over a given time and the material parameters such as stiffness, modulus, viscosity, hardness, strength or toughness are determined by considering the subsequent forces or stresses (Dobraszczyk and Morgenstern, 2003). Bread is an excellent source of nutrients as well as non-nutrient compounds. Higher consumption of bread baked from whole meal flour will increase consumption of dietary fiber in an average daily diet. World Health Organization (WHO) recommends that intake of fiber should be between 25-40 g per day (WHO/FAO, 2003), whereas in different populations it is usually too low. The acceptability of any food product like bread is subjected to a number of factors such as effect of climate, geographical location, consumer's age and level of income along with other factors. Breads are mostly made from flour of high extraction rate. So, the sensory qualities of breads including color, texture, chew ability may be closely examined because as the time passes, breads lose their commercial value through sensory changes which are due to physical and chemical deterioration (Park et al., 2006). Bread has a great importance in human nutrition as a protein and carbohydrate source. In Egypt, cereal based products especially bread has great importance in diets, $66 \%$ of the energy consumed per capita is supplied from cereals and $56 \%$ of this energy is supplied only from breads (Elgün et al., 2007). From the bread making point of view, wheat 
(Triticum aestivum) is the most important crop. The wheat kernel consists of germ, pericarp layers (outer and inner), seed coat, aleurone layer and starchy endosperm. The objective of milling is to separate the starchy endosperm from the kernel, and to ground it into flour. The aleurone layer, pericarp layer and seed coat form the bran. Flours differ in their extraction rate, chemical and nutritional compositions. White flour is produced when the extraction rate is $75 \%$ or less, and whole meal flour is generated when the extraction approaches $100 \%$. When white flour is produced, many important nutrients and fibers are removed, because these components are mainly located in bran and germ. Therefore ,the whole meal flour provides good bread in terms of nutritional value and health benefits (Dewettinck et al., 2008). Dough aeration not only affects the rheology of the static dough through physical presence of gas bubbles following mixing, but also affects the development of its rheological properties within the mixer, as the gas bubbles affect the rate of work input that develops the dough and the turnover of air that supplies oxygen to facilitate this development (Chin et al., 2009). Baladi bread is an Egyptian product that represents the main diet component for rich and poor Egyptian consumers. In Egypt, there is a big gap between wheat production and its consumption, where the total production of wheat grains covers only about $55 \%$ of the total needs (Yaseen et al., 2010).

According to WHO criteria, anaemia in most worldwide countries represents a major public health problem. The results of the investigations drown under UNICEF supervision over a group of 792 children under 5 years old and their mothers show anaemia presence at $47 \%$ of children between 6 and 12 months old, at $28 \%$ of children under 5 years old and at $40 \%$ of women of fertile age. According to the statistics of the Ministry of Health, anaemia rate in the case of children till one year old constitutes $20 \%$. It is known, that one anaemia case corresponds to one case of iron nutritional deficiency, and it is possible to assume that approximately half of the children under 5 years old and $40 \%$ of fertile age women have iron deficiency. Prevalence of blood and haematopoietic system diseases increased during the last 5 years with $46.4 \%$ and for anaemia with 50.3\% (UNICEF, 1996-2000). Anaemia affects 1.62 billion people globally, corresponding to $24.8 \%$ of the world population (McLean et al., 2009). Iron deficiency is the most common cause and even in the developed world an estimated 30- $40 \%$ of preschool children and pregnant women have iron depletion (WHO, 2008). 


\section{Materials And Methods \\ Materials: \\ a. Wheat flour: \\ Soft wheat flour $(72 \%$ extraction) and wheat flour $(82 \%$ extraction) were obtained from local market, Damietta Governorate, Egypt. \\ b. Rats:}

Eighteen male white albino rats of Sprague Dawley, weighting $(135 \mathrm{~g} \pm 5 \mathrm{~g})$ were obtained from Research Institute of Ophthalmology, Medical Analysis Department, Dokki, Giza, Egypt.

\section{c. Casein:}

Casein as main source of protein obtained from Technogen Company for Chemicals and Drugs, Giza, Egypt.

d. Cellulose, vitamin mixture, salt mixture, starch and corn oil :

Cellulose, vitamin mixture, salt mixture and starch were purchased from El - Gomhoria Co., Cairo, Egypt. While, corn oil was purchased from local market, Giza, Egypt.

\section{e. Ferrous sulfate:}

Ferrous sulfate was purchased from El - Gomhoria Co., Cairo, Egypt.

\section{Methods:}

Technological methods :

Preparation of Kemmak bread:

Pan Kemmak bread was prepared from soft flour (72\% extraction). The baking formula of control sample was as follow: $1000 \mathrm{~g}$ flour, $833.3 \mathrm{~g}$ milk, $1.66 \mathrm{~g}$ yeast , $41.66 \mathrm{~g}$ butter, $16.66 \mathrm{~g}$ oil , $0.83 \mathrm{~g}$ sugar, $0.83 \mathrm{~g}$ salt, $2.66 \mathrm{~g}$ baking powder , $0.33 \mathrm{~g}$ vanilla , $8.33 \mathrm{~g}$ sesame and $16.6 \mathrm{mg}$ Ferrous sulfate.

\section{Preparation Of Baladi Bread :}

Pan Baladi bread was prepared from mixture of wheat flour $(82 \%$ extraction) and soft flour (72\% extraction) (5:1). The baking formula of control sample was as follow: $1000 \mathrm{~g}$ mixture of wheat flour and soft flour, $1.66 \mathrm{~g}$ yeast, $833.3 \mathrm{~g}$ water, $1.66 \mathrm{~g}$ salt, $0.83 \mathrm{~g}$ sugar, 2.66 baking powder and $16.6 \mathrm{mg}$ ferrous sulfate, according to the methods described by (Nadine et al., 2012) .

Analytical methods:

Moisture, Protein (N x 6.25 Keldahl method), fat (hexane solvent, Soxhielt apparatus), fiber and ash were determined according to the method recommended by A. O. A. C. (2010).

Carbohydrates and energy value:

Carbohydrate was calculated by differences as follows: 
$\%$ Carbohydrates $=100-(\%$ moisture $+\%$ protein $+\%$ fat $+\%$ ash $+\%$ fiber).

Energy value was estimated by the sum of multiplying protein and carbohydrates by 4.0 and fat by 9.0 according to FAO (1982).

\section{Determination of Iron:}

Baladi bread and kemmak bread were spplemented by ferrous sulfate at ratio $16.6 \mathrm{mg} / \mathrm{kg}$ according to the method describe by (Nadine et al., 2012).

\section{Determination of Total Iron Binding Capacity:}

Serum iron and total iron binding capacity (TIBC) were measured by using the method described by (Fielding, 1980). The serum from each animal was used for analysis of iron and TIBC using a kit from Sigma, and the assays were performed by Genox, by using a Cobas Fara II Chemical Analyzer.

\section{Rheological properties:}

Farinograph tests:

All flour dough blends were tested by using, farinograph apparatus, to determine water absorption (\%), arrival time (min.), dough development time (min.), dough stability (min.) and dough weakening (B.U) according to the methods described by (A.A.C.C. 1990).

\section{Extensograph tests:}

All flour doughs blends were tested by using extensograph apparatus, to determine dough energy $\left(\mathrm{cm}^{2}\right)$, dough extensibility $(\mathrm{E})$ $(\mathrm{mm}$.), resistance to extension (R) (B.U) and proportional number (R/E) according to the methods described by (A.A.C.C. 1990).

\section{Anti - nutritional:}

The tannin content was determined using the Vanillin- $\mathrm{HCl}$ reagent method of (Burns, 1971). The oxalate content of the samples was determined using the potassium permanganate titration method of (Dye, 1956), while the phytic acid content was determined using the method of (Mc Cance and Widdowson, 1935).

\section{Physical properties:}

Bread characteristics or baking qualities were evaluated as method described of (See et al., 2007) by measuring loaf height, loaf volume and specific volume, $30 \mathrm{~min}$ after removal from the oven. Loaf volume was determined using the rapeseed displacement method, bussing alfalfa seeds instead of rapeseeds. Each loaf $(n=6)$ was weighed and the volume was measured $60 \mathrm{~min}$ after being taken from the oven. The specific loaf volume was reported as $\mathrm{cm}^{3} / \mathrm{g}$ of the loaf.

\section{Experimental design:}

The experimental was done in Research Institute of Ophthalmology, Medical Analysis Department, Dokki, Giza, Egypt . Eighteen adult male white albino rats, Sprague Dawley Strain, 10 weeks 
age, weighing $(135 \pm 5 \mathrm{~g})$ were used in this experiment. All rats were fed on basal diet (casein diet) prepared according to American Institute of Nutrition (AIN) (1993) for 7 consecutive days. After this adaptation period, rats are divided into 3 groups, each group which consists of six rats as follows: The first group was fed on the basal diet only, as a control negative (healthy rats). The second group was fed on Kemmak bread powder fortified with iron (Ferrous sulfate at $16.6 \mathrm{mg}$ ) was add as replacement from starch $100 \%$.The third group was fed on Baladi bread powder fortified with iron (Ferrous sulfate at $16.6 \mathrm{mg}$ ) was add as replacement from starch $100 \%$.

Blood sampling:

After fasting for 12 hours, blood samples in initial times were obtained from retro orbital vein, while it obtained from hepatic portal vein at the end of each experiment. Two kinds of blood samples were taken. The first parts of blood samples were collected into a dry clean centrifuge glass tubes and left to clot in water bath $\left(37^{\circ} \mathrm{C}\right)$ for 30 minutes, then centrifuged for 10 minutes at $4000 \mathrm{rpm}$ to separate the serum, which were carefully aspirated and transferred into clean cuvette tube and stored frozen in deep freezer till analysis.

\section{Results And Discussion}

1. Chemical composition of wheat flour (82\% extraction) and soft flour (72\% extraction ).

Data presented in table (1) show the chemical composition of wheat flour (82\% extraction). It is clear to notice that the protein, fat, fiber and carbohydrates contents of wheat flour were 11.78, 1.67, 1.15 and $74.60 \%(\mathrm{~W} / \mathrm{W})$, respectively while, the energy value was 360.55 $\mathrm{kcal} / 100 \mathrm{~g}$. These results are in agreements with (Seleem, 2000). They found that the protein, fat, fiber and carbohydrates content of wheat flour were $12.80,1.91,1.93$ and $82.30 \%$, respectively.

Data given in table (2) show the chemical composition of soft flour (72\% extraction). It is clear to notice that the protein, fat, fiber and carbohydrates content of wheat flour were 15.06, $1.05,0.03$ and $71.90 \%(\mathrm{~W} / \mathrm{W})$, respectively while, the energy value was $357.29 \mathrm{kcal} /$ 100g.. These results are in agreements with (Seleem, 2000). They found that the protein, fat, fiber and carbohydrates content of wheat flour were $11.85,1.06,0.54$ and $86.04 \%$, respectively.

\section{Rheological properties of dough:}

The parameters of farinograph diagram are represented in table (3). It is clear to notice that water absorption, arrival time, dough development and degree of softening of Baladi bread (wheat flour $82 \%$ extraction) recorded the highest value compared with Kemmak bread. The values were $61.5 \%, 1.0 \mathrm{~min}, 1.5 \mathrm{~min}$ and $130.0 \mathrm{BU}$, respectively. 
On the other hand, stability of Kemmak bread (soft flour $72 \%$ extraction) recorded the highest value. The value was $6.0 \mathrm{~min}$, respectively. These results are in agreement with (Saha et al., 2011). They found that the increasing in fiber and protein contents of whole wheat flour caused increasing in the water absorption this can be attributed to that fiber is more water absorption than that the flour.

Data presented in table (4) show the extensograph of Baladi and Kemmak bread. It is clear to mention that elasticity, extensibility, P.N and energy of Kemmak bread (soft flour $72 \%$ extraction) recorded the highest value, compared with Baladi bread. The values were (230 BU, $128 \mathrm{~min}, 1.82$ and $\left.49 \mathrm{~cm}^{2}\right)$ and $\left(180 \mathrm{BU}, 115 \mathrm{~min}, 1.57\right.$ and $\left.31 \mathrm{~cm}^{2}\right)$, respectively. These results are in agreement of (Karaoglu, 2006).

\section{Physical properties:}

Data presented in table (5) show the physical properties of Balabi and Kemmak bread. It is clear to notice that the highest values of weight, volume, specific volume and diameter recorded with Baladi bread with significant differences. While, the lowest one recorded with Kemmak bread. The values were $(80 \mathrm{~g}, 810 \mathrm{cc}, 16.9 \mathrm{cc} / \mathrm{g}$ and, $12.7 \mathrm{~mm}$, respectively) and (52.5g, $575 \mathrm{cc}, 11.4 \mathrm{cc} / \mathrm{g}$ and $9.75 \mathrm{~mm}$, respectively). These results are in agreements with (Song Hwan and Chul, 1999). They found that the weight, volume and specific volume content of Baladi bread were 120.11, 291 and 2.42, respectively. On the other hand, data also obtained from table (5) showed that, Kemmak bread recorded higher values of spread ratio and thickness with significant differences compared with Baladi bread. The values were $14.1 \mathrm{D} / \mathrm{T}$ and $1.96 \mathrm{~mm}$ ) and (10.6 D/T and $0.84 \mathrm{~mm})$, respectively. On the other hand, the values of diameter, spread ratio and thickness were $(12.7 \mathrm{~mm}, 10.6(\mathrm{D} / \mathrm{T})$ and 0.84 $\mathrm{mm}$, respectively) for Baladi bread with significant differences. While, values were $9.75 \mathrm{~mm}, 14.1 \mathrm{D} / \mathrm{T}$ and $1.96 \mathrm{~mm}$, respectively for Kemmak bread with significant differences. These results are in agreements with (Yildiz, 2009). They found that the diameter, spread ratio and thickness content of Baladi bread were $16.7 \mathrm{~mm}, 12.6 \mathrm{D} / \mathrm{T}$ and $1.34 \mathrm{~mm}$, respectively. These results are in agreements with (Hooda \& Jood, 2005 and Sudha et al., 2007). They found that the weight, volume, specific volume, diameter, spread ratio and thickness content of Kemmak bread were $30.50 \mathrm{~m}, 250 \mathrm{cc}, 8.2 \mathrm{cc} / \mathrm{g}, 6.67 \mathrm{~mm}, 11.87 \mathrm{D} / \mathrm{T}$ and $1.37 \mathrm{~mm}$, respectively.

\section{Anti-nutritional value:}

Anti-nutritional composition of Balabi and Kemmak bread $(\mathrm{mg} / 100 \mathrm{~g})$ are shown in table (6). It is clear to notice that the tannins content in Baladi bread was higher than Kemmak bread with non significant differences $(\mathrm{p}<0.05)$. The value were 125.63, 123.26, respectively. While, phytayes content in Baladi bread was higher than 
Kemmak bread with non significant differences $(\mathrm{p}<0.05)$. The value were 298.00, 295.16, respectively. In case of oxalates content, the results indicated that the Baladi bread content was lower than Kemmak bread with significant differences $(\mathrm{p}<0.05)$. The value were 26.40, 35.20 , respectively. These results are in agreement of (Gallagher et al., 2003). They found that the phytic acid levels in the bread and flour samples were quite high. The tannin content was also high. The concentrations of phytic acid and tannins in the bread and flour were however not alarming when compared with their concentrations in other food stuffs.

\section{Effect of Kemmak and Baladi bread on iron ( $\mathrm{mg} / \mathrm{dl})$ in rats}

Data tabulated in table (7) showed that iron ( $\mathrm{mg} / \mathrm{dl})$ for different rats fed basal diet (negative control) and fed on Kemmak and Baladi bread fortified with iron as ferrous sulfate. Concerning that ( mean \pm SD) was $(146 \pm 9.16)$ for control group , $(157 \pm 4.58)$ for Kemmak bread group , $(134.33 \pm 10.21)$ for Baladi bread group. The data showed that mean value of iron of Kemmak bread group was higher when compared with control group, increasing the level of experimental diet leads significant differences $(\mathrm{p}<0.05)$. These results are in agreement with (Aggett et al ., 2012). They mentioned that iron is necessary for growth, development, normal cellular functioning, and synthesis of some hormones and connective tissue. Also, (Anon, 2012) mentioned that present in all cells of the human body, iron is a mineral that has several vital functions. As the major part of hemoglobin in red blood cells, it carries oxygen from the lungs to all parts of the body and facilitates oxygen use and storage in muscles. Every cell in the body needs iron to produce energy.

Data tabulated in table (8) showed that total iron binding capacity ( $\mathrm{mg} / \mathrm{dl}$ ) for different rats fed basal diet (negative control) and fed on Kemmak and Baladi bread fortified with iron as ferrous sulfate. Concerning that ( mean $\pm \mathrm{SD})$ was $(335 \pm 11.35)$ for control group , $(324.66 \pm 9.07)$ for Kemmak bread group , $(363 \pm 10.44)$ for Baladi bread group. The data showed that mean value of total iron binding capacity of Baladi bread group was higher when compared with control group. significant differences increases were recorded for Baladi bread $(p<0.05)$ when compared with control negative, while high significant differences were recorded for Kemmak bread $(\mathrm{p}<0.01)$. These results are in agreement with (Anon , 2008). He mentioned that total ironbinding capacity (TIBC) is a medical laboratory test that measures the blood's capacity to bind iron with transferrin. It is performed by drawing blood and measuring the maximum amount of iron that it can carry, which indirectly measures transferring since transferrin is the most 
dynamic carrier. TIBC is less expensive than a direct measurement of transferrin.

Table (1): Chemical composition of wheat flour (82\% extraction)

\begin{tabular}{l|c|c}
\multicolumn{1}{c|}{ Components } & $(\mathbf{W} / \mathbf{W})$ & $(\mathbf{D} / \mathbf{W})$ \\
\hline Moisture & 9.85 & ---- \\
Protein & 11.78 & 13.07 \\
Fat & 1.67 & 1.85 \\
Fiber & 1.15 & 1.28 \\
Ash & 0.95 & 1.05 \\
Carbohydrates & 74.60 & 82.75 \\
Energy value (Kcal/100gm) & 360.55 & --- \\
\hline
\end{tabular}

Table (2): Chemical composition of soft flour (72\% extraction).

\begin{tabular}{l|c|c}
\hline \multicolumn{1}{c|}{ Components } & $(\mathbf{W} / \mathbf{W})$ & $(\mathbf{D} / W)$ \\
\hline Moisture & 11.44 & --- \\
Protein & 15.06 & 17.01 \\
Fat & 1.05 & 1.19 \\
Fiber & 0.03 & 0.03 \\
Ash & 0.52 & 0.59 \\
Carbohydrates & 71.9 & 81.18 \\
Energy value (Kcal/100gm) & 357.29 & 100.684 \\
\hline
\end{tabular}

Table (3): Farinograph of Baladi and Kemmak bread .

\begin{tabular}{c|c|c|c|c|c}
\hline Samples & $\begin{array}{c}\text { Water } \\
\text { absorption } \\
(\%)\end{array}$ & $\begin{array}{c}\text { Arrival } \\
\text { time } \\
\text { (min) }\end{array}$ & $\begin{array}{c}\text { Dough } \\
\text { development } \\
\text { (min) }\end{array}$ & $\begin{array}{c}\text { Dough } \\
\text { stability } \\
\text { (min) }\end{array}$ & $\begin{array}{c}\text { Degree of } \\
\text { softening } \\
\text { (B.U) }\end{array}$ \\
\hline $\begin{array}{c}\text { Kemmak } \\
\text { (72\% Extr.) }\end{array}$ & 58.5 & 0.5 & 1.0 & 6.0 & 80.0 \\
\hline $\begin{array}{c}\text { Baladi bread } \\
\text { (82\% Extr) }\end{array}$ & 61.5 & 1.0 & 1.5 & 5.5 & 130.0 \\
\hline
\end{tabular}

Extr. $=$ Extraction 
Table (4): Extensograph of Baladi and Kemmak bread.

\begin{tabular}{c|c|c|c|c}
\hline Samples & $\begin{array}{c}\text { Elasticity } \\
(\mathbf{B . U})\end{array}$ & $\begin{array}{c}\text { Dough } \\
\text { extensibility } \\
(\mathbf{m m})\end{array}$ & P.N & $\begin{array}{c}\text { Dough } \\
\text { energy } \\
\left(\mathbf{c m}^{\mathbf{2}}\right)\end{array}$ \\
\hline $\begin{array}{c}\text { Kemmak } \\
\text { (72\% Extr.) }\end{array}$ & 230 & 128 & 1.82 & 49 \\
\hline $\begin{array}{c}\text { Baladi bread } \\
\text { (82\% Extr.) }\end{array}$ & 180 & 115 & 1.57 & 31 \\
\hline
\end{tabular}

Extr. $=$ Extraction

Table (5): Some physical properties of Balabi and Kemmak bread .

\begin{tabular}{|c|c|c|c|c|c|c|}
\hline $\begin{array}{c}\text { Physical } \\
\text { Properties }\end{array}$ & $\begin{array}{c}\text { Weight } \\
\text { (g) }\end{array}$ & $\begin{array}{l}\text { Volume } \\
\text { (cc) }\end{array}$ & $\begin{array}{l}\text { Specific } \\
\text { volume } \\
\text { (cc/g) }\end{array}$ & $\begin{array}{l}\text { Diameter } \\
(\mathbf{m m})\end{array}$ & $\begin{array}{c}\text { Spread } \\
\text { ratio } \\
(\mathrm{D} / \mathrm{T})\end{array}$ & $\begin{array}{c}\text { Thickness } \\
\text { (mm) }\end{array}$ \\
\hline $\begin{array}{l}\text { Baladi } \\
\text { bread }\end{array}$ & $\begin{array}{c}80 \pm \\
0.11^{\mathrm{a}} \\
\end{array}$ & $\begin{array}{l}810 \pm \\
0.25^{\mathrm{a}} \\
\end{array}$ & $\begin{array}{l}16.9 \pm \\
0.12^{\mathrm{a}} \\
\end{array}$ & $\begin{array}{l}12.7 \pm \\
0.42^{\mathrm{a}}\end{array}$ & $\begin{array}{l}10.6 \pm \\
0.15^{\mathrm{b}}\end{array}$ & $\begin{array}{l}0.84 \pm \\
0.04^{\mathrm{b}}\end{array}$ \\
\hline $\begin{array}{l}\text { Kemmak } \\
\text { Bread }\end{array}$ & $\begin{array}{l}52.5 \pm \\
0.13^{\mathrm{b}}\end{array}$ & $\begin{array}{l}575 \pm \\
0.15^{\mathrm{b}}\end{array}$ & $\begin{array}{l}11.4 \pm \\
0.23^{\mathrm{b}}\end{array}$ & $\begin{array}{l}9.75 \pm \\
0.31^{\mathrm{b}}\end{array}$ & $\begin{array}{l}14.1 \pm \\
0.13^{\mathrm{a}}\end{array}$ & $\begin{array}{l}1.96 \pm \\
0.02^{\mathrm{a}}\end{array}$ \\
\hline
\end{tabular}

Table (6): Anti-nutritional composition of Balabi bread and Kemmak bread (mg/100 g).

\begin{tabular}{c|c|c}
\hline Anti-nutritional & Balabi bread & Kemmak bread \\
\hline Tannins & $125.63^{\mathrm{a}} \pm 0.20$ & $123.26^{\mathrm{a}} \pm 0.15$ \\
\hline Phytates & $298.00^{\mathrm{a}} \pm 0.22$ & $295.16^{\mathrm{a}} \pm 0.15$ \\
\hline Oxalates & $26.40^{\mathrm{a}} \pm 0.20$ & $35.20^{\mathrm{b}} \pm 0.20$ \\
\hline
\end{tabular}

$*$ Mean of three determinations \pm standard deviation. 
Table (7): Effect of Kemmak and Baladi bread on iron ( $\mathrm{mg} / \mathrm{dl})$ in rats.

\begin{tabular}{l|c}
\hline Groups & Parameter \\
Control & Mean \pm SD \\
T.test & $146 \pm 9.16$ \\
\hline Kemmak bread & - \\
T.test & $157 \pm 4.58$ \\
Baladi bread & $-4.158 *$ \\
T.test & $134.33 \pm 10.21$ \\
\hline \multicolumn{2}{c}{$*$ Significant differences $(\mathrm{p}<0.05)}$. \\
\hline
\end{tabular}

Table (8): Effect of Kemmak and Baladi bread on total iron binding capacity ( $\mathrm{mg} / \mathrm{dl})$ in rats

\begin{tabular}{|c|c|}
\hline Groups Parameter & $\begin{array}{c}\text { TIBC } \\
\text { Mean } \pm \text { SD }\end{array}$ \\
\hline $\begin{array}{l}\text { Control } \\
\text { T.test }\end{array}$ & $\begin{array}{c}335 \pm 11.35 \\
-\end{array}$ \\
\hline $\begin{array}{l}\text { Kemmak bread } \\
\text { T.test }\end{array}$ & $\begin{array}{c}324.66 \pm 9.07 \\
7.750 * *\end{array}$ \\
\hline $\begin{array}{l}\text { Baladi bread } \\
\text { T.test }\end{array}$ & $\begin{array}{c}363 \pm 10.44 \\
-4.303 *\end{array}$ \\
\hline
\end{tabular}




\section{References}

A.A.C.C. (1990): Approved Methods of the American Association of Cereal Chemists. Published by A.A.C.C., st. Paul Mn., U.S.A.

Aggett, P.J.; Erdman, J.W.; Macdonald, I.A. and Zeisel, S.H. (2012): Iron: In, eds. Present Knowledge in Nutrition, $10^{\text {th }}$ Ed., Wiley-Washington, USA ,DC .

AIN (1993): American institute of nutrition purified diet for laboratory Rodent, Final Report. J. Nutrition, 123: 1939-1951 and O. Compactum Benth. J. Essential Oil Res., 8 (6): 657-664.

Anon, (2008):"MedlinePlus Medical Encyclopedia: Total iron binding capacity". Retrieved 2008-12-31.

Anon, (2012): California Nutrition and Physical Activity Guidelines for Adolescents; Funded by Federal Title V Block Grant through the Maternal, Child and Adolescent Health Division, Center for Family Health.

A. O. A. C. (2010): Official Methods of the Association of Official Analytical Chemists, 15 ${ }^{\text {th }}$ Ed. ,AOAC 2200 Wilson Boulevard Arling, Virginia, 22201, U.S.A.

Burns, R. E.(1971): Methods for estimation of tannins in grains sorghum. J. Agronomy, 163: 511-513.

Chin , N.L. ; Tan , L.H. ; Yusof , Y.A. and Rahman , R.A. (2009): Relationship between aeration and rheology of bread . Journal of Texture Studies, 40:727 - 738.

Dewettinck, K.; Van Bockstaele, F.; Kuhne, B.; Van de Walle, D.; Courtens, T.M. and Gellynck, X.( 2008): Nutritional value of bread: Influence of processing, food interaction and consumer perception. Journal of Cereal Science, 48: 243-257.

Dobraszczyk, B.J. and Morgenstern, M.P.( 2003): Rheology and the breadmaking process. J. Cereal Sci., 38(3):229-245.

Dye, W. B.(1956):Chemical studies on Halogetotsgloniieratius. Weeds, 4: $55-60$

Elgün, E.; Türker, S. and Bilgiçli, N. N.(2007): Tahıl Ürünleri Teknolojisi, Selçuk University Food Engineering Department, Turkey.

FAO (Food and Agriculture Organization), (1982): Food Composition Tables for the Near East, F.A.O., Food and Nutrition, Paper, 26. 
Fielding, J. (1980): Iron. Methods Hematology Journal, 1: 15-43.

Gallagher, F.; Gormley, T.R. and Arendt, E.K. (2003): Crust and crumb characteristics of gluten free breads. Journal of Food Engineering, 56: 153-161.

Hooda, S. and Jood, S.( 2005 ): Organoleptic and nutritional evaluation of wheat biscuits supplemented with untreated and treated fenugreek flour. Food Chem., 90: 427-435.

Karaoglu, M. M. (2006): Effect of baking procedure and storage on the pasting properties and staling of part-baked and rebaked white pan bread crumb. Int. J. Food Prop., 9:609-622.

McCance, R. A. and Widdowson, E.M.(1935): Phytin in human nutrition. Biochem. J., 29 (12): 2694-2699.

McLean, E.; Cogswell, M.; Egli, I.; Wojdyla, D. and de Benoist, B. (2009): Worldwide prevalence of anaemia, WHO Vitamin and Mineral Nutrition Information System 1993-2005. Public Health Nutrition, 12: 444-454.

Mousa, E.I.; Ibrahim, R.H.; Shuey, W.C. and Maneval, R.D. (1979): Influence of wheat classes, flour extraction, and baking methods on Egyptian balady bread. Cereal Chem., 56: 563 - 566.

Nadine , E. ; Arnaud, L. ; Anwar, N. ; Rukia , Y. and Magdy , S. (2012): Fortifying baladi bread in Egypt : Reaching more than 50 million people through the subsidy program. Food and Nutrition Bulletin, vol. 33, no. 4: (supplement), The United Nations University.

Park, Y.H.; Jung , L.H. and Jeon, E.R. (2006): Quality characteristics of bread using sourdough. J. Food. Sci. Nut., 33: 323-327.

Raport UNICEF (1996- 2000): Starea de nutriţie în Republica Moldova, 38.

Saha, S.; Gupta, A.; Singh, S. R. ; Bharti, N.; Singh, K. P.; Mahajan, V. and Gupta, H. S. (2011): Compositional and varietal influence of finger millet flour on rheological properties of dough and quality of biscuit. LWT - Food Science Technology, 44: 616-621.

See, E.F.; Wan Nadiah, W.A. and Noor Aziah, A.A. (2007): Physicochemical and sensory evaluation of breads supplemented with pumpkin flour. ASEAN Food Journal ,14(2):123-30. 
Seleem, H. A. S. (2000): Studies on Addition of Some Corn and Sorghum Varieties to Wheat Flour and Balady Bread Characteristic. Ph.D. Thesis, Fac. Agric., Cairo Univ., Egypt.

Song Hwan, B. and Chul, R. (1999): Effect of soybean protein isolates on the baking qualities of bread. Korean J. Food Sci. Technology, 30: 1295.

Sudha, M.; Vetrimani, R. and Leelavathi , K.(2007): Influence of fibre from different cereals on the rheological characteristics of wheat flour dough and on biscuit quality. Food Chem., 100: $1365-1370$.

WHO (2008): Worldwide Prevalence of Anaemia 1993-2005: WHO Global Database on Anaemia / Edited by Bruno de Benoist, Erin McLean, Ines Egli and Mary Cogswell.

WHO/FAO(World Health Organization/Food and Agriculture Organization ), (2003): Report on Joint WHO/FAO Expert Consultation. Diet, Nutrition and the Prevention of Chronic Diseases, Geneva.

Yaseen, A. A.; Shouk, A.A. and Ramadan, M.T. ( 2010): Corn-wheat pan bread quality as affected by hydrocolloids. J. Amer. Sci., 6 (10): 684-690.

Yildiz, G. (2009): Karabuğday ununun (Fagopyrum esculentum Moench) ununun geleneksel Türk ekmeklerinde kullanılma imkanları üzerine araştırmalar, M. Thesis, Selçuk University, Food Engineering Department, Master Thesis, Konya, Turkey. 


\title{
تقييم القيمة الغذائية للكماج والخبز البلدى المنتج فى محافظة دمياط
}

\author{
عماد محمد الخولى ـ طارق محمد عبد الرحمن ـ أميرة أحمد حمودة \\ كلية الأقتصاد المنزلى ـ جامعة المنوفية_قسم التغذية و علوم الأطعمة الرمدة
}

تم فى هذا البحث تقييم الخبز البلدي و الكماج المنتج في محافظة دمياط عن التبان

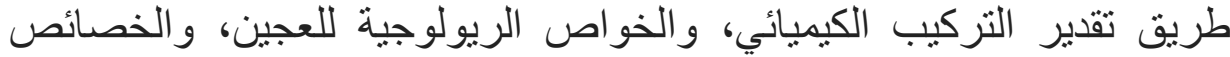

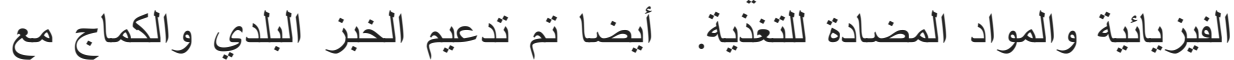

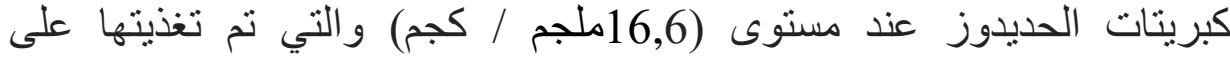

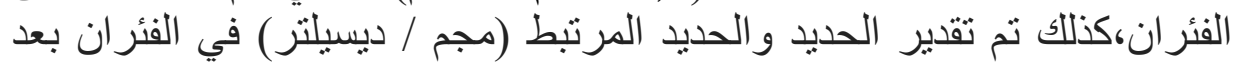

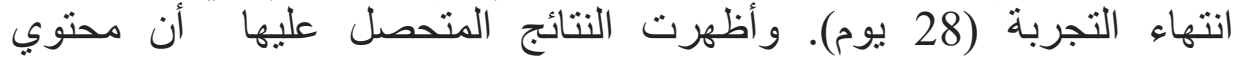

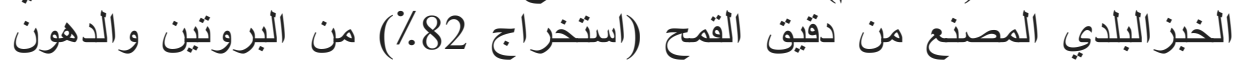

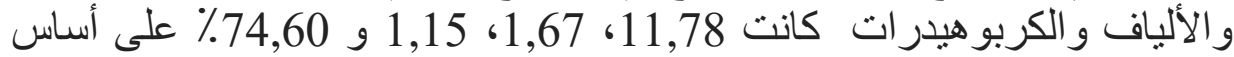
الوزن الرطب على التوالي في حين بلغت قيمة الطاقة

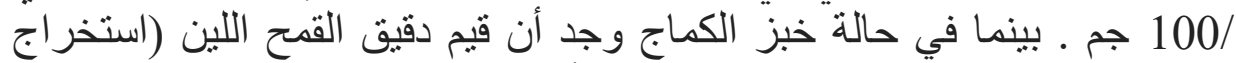

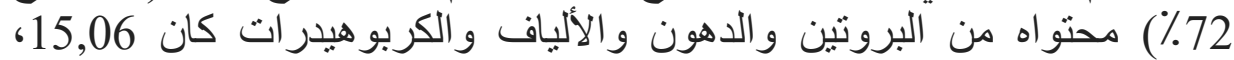

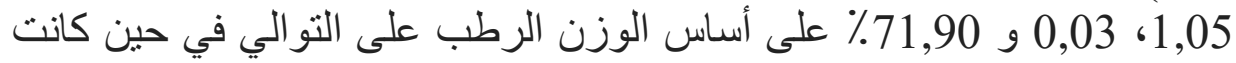

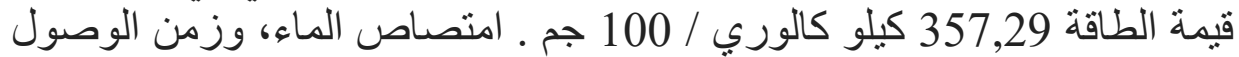

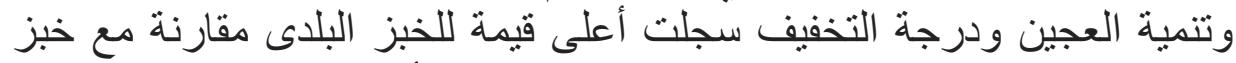

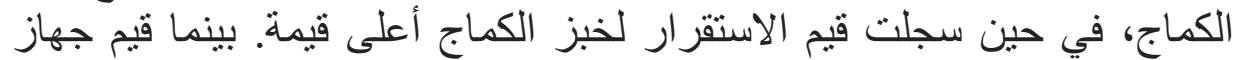
الأكستنسوجر فاف مثل المرونة و التمدد، و الـ PN و الطاقة سجلت أعلى العلى قيمة للكماج

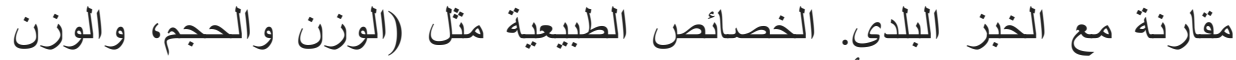

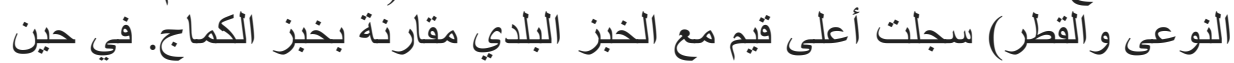

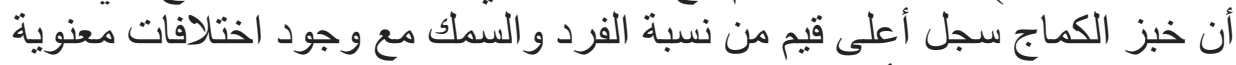

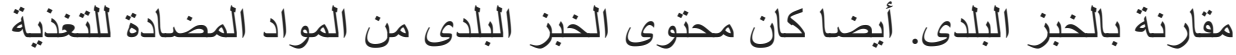

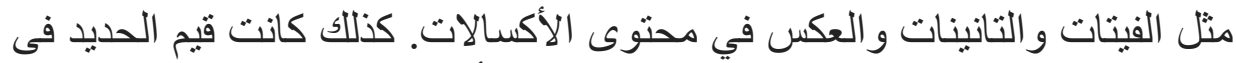

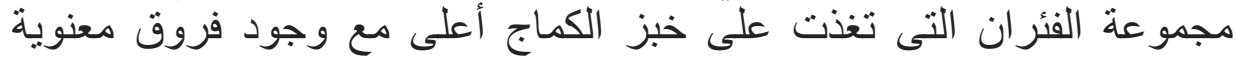

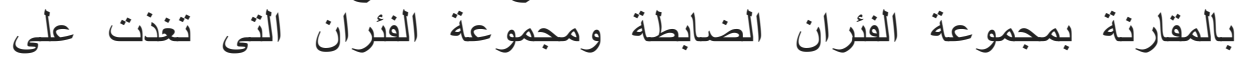

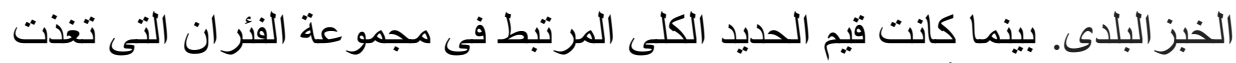

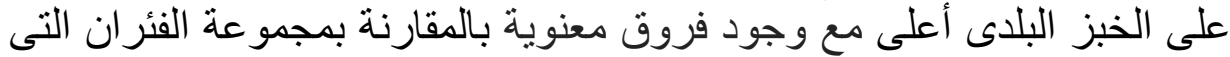

تغذت على خبز الكماج و المجمو عة الضابطة. الكلمات الدالة: الخبز البلاى ـ خبز الكماج ـ الفئر ان ـ الجودة 